\title{
How Drought Affects Agricultural Insurance Policies: The Case of Italy
}

\author{
Giulio Fusco ${ }^{1}$, Pier Paolo Miglietta ${ }^{1} \&$ Donatella Porrini ${ }^{1}$ \\ ${ }^{1}$ University of Salento, Italy \\ Correspondence: Pier Paolo Miglietta, University of Salento, Italy. E-mail: pierpaolo.miglietta@unisalento.it
}

Received: December 19, 2017

Accepted: January 22, 2018

Online Published: February 10, 2018

doi:10.5539/jsd.v11n2p1

URL: https://doi.org/10.5539/jsd.v11n2p1

\begin{abstract}
Despite their growing intensity and the enormous costs, adverse meteorological events are still perceived as "exceptional". Among the adverse weather events, the management of drought risk plays a key role due to the more pressing problem of the scarcity of water resources. In this context, agricultural insurance can represent a financial and risk mitigation tool for farmers. In this perspective, the aims of this study are: (1) to analyze, through a systematic review, the main findings of the scientific literature focused on the empirical and theoretical approach to the relation between adverse weather events in agriculture, risk and insurance; (2) to collect agroclimatic and insurance data for each Italian province for the period 2004-2011, (3) to measure the influence of climatic agroclimatic variables on insurance variables, i.e. Total Premiums, Insured Value and Certificates.

The results of the analysis show the significance of the precipitation variable and its negative effect with each insurance dependent variable. The same result can be observed focusing on the effect of minimum temperature on two insurance variables, i.e. Total Premiums and Certificates. Models tested explain a range between $44 \%$ and $51 \%$ of the variation in our insurance dependent variables.
\end{abstract}

Keywords: agriculture, drought, insurance, risk management, mitigation

\section{Introduction}

In the summer 2017, record temperatures and a long period without rain created a relevant phenomenon of water scarcity in Italy. As a consequence, eleven of the 20 regions, from Veneto in the north to Sicily in the south, including the Lazio region around Rome, asked for a state of emergency to be declared in order to help tackle the ongoing drought. The Italian government declared a state of emergency in geographical areas characterized by very specialized and precious gastronomic productions, such as high quality tomatoes, cheese and wine grapes. The farmers' association Coldiretti said the agriculture sector suffered losses of at least $€ 2 \mathrm{bn}$.

Traditional risk management strategies have often proven to be effective in preventing serious economic loss and allowing for a speedy recovery (Gómez Gómez and Perez Blanco, 2012). The management of risk in agriculture and the role of insurance have been the center of attention for researchers and policymakers.

Moreover, recent changes in the Common Agricultural Policy have focused their attention on the possibility of an enlarged crop insurance program in Europe (EU Regulation 1305/2013). Several countries in the European Union already have national crop insurance schemes, but the performance of these programs in terms of demand realized has been low. In some cases, such as Italy, participation in the programs remains low in spite of significant subsidies to insurance premiums (Landini, 2015).

In reality, many obstacles limit the development of an efficient and sustainable agricultural insurance system: lack of high quality information, inadequate regulatory frameworks, a mass of low- income dispersed clients who may not be willing or able to pay actuarially sound premiums, and the tendency of governments to undermine market development through inappropriate use of subsidies and disaster relief funds.

Scientific research is needed to analyze the reasons why, even with strong public support, insurance penetration is not as high as could be expected. Up until now, reasons for such failures are usually found in either supply or demand conditions.

On the supply side, the most explored issues are asymmetric and incomplete information, with the resulting problems of adverse selection, moral hazard and systemic risk. 
The latter prevents crop insurers from achieving gains pooling individual risks since unfavorable events, such as droughts, simultaneously affect a large number of agricultural areas and generate a significant correlation among individual crop risks (Mahul and Vermersch, 2000).

On the demand side, one identified reason is the inability of farmers to assess precisely the benefits deriving from agricultural insurance; another explanation is the massive government intervention that may influence the decision to purchase a costly insurance policy.

Knowledge of factors affecting the penetration of crop insurance is essential for evaluating the soundness of insurance programs and the consequent public support. In spite of its importance, the demand for crop insurance has received little empirical attention in literature, which has been mainly focused on developing countries cases or on the North America experience; for European countries the lack of empirical evidence is even greater.

Moreover, the diffusion of insurance could have positive effects in different directions, contributing to the general objective of sustainability (Costanza, 1991) and resilience: firstly, by providing policies covering claims by parties who allege damage (ex-post recovery); secondly by introducing incentives for risk-reduction behavior (mitigation), as it is shown in Figure 1.

The resilience approach offers a way to conceptualize uncertainty and dynamics, requiring the understanding of processes, and of the conditions that enable them. Furthermore, the resilience approach requires the understanding of how farmers make sense of their current situation, how and when they choose to adapt their processes in the face of emerging issues, and how they recover from consequences of unfavorable events (Darnhofer, 2014).

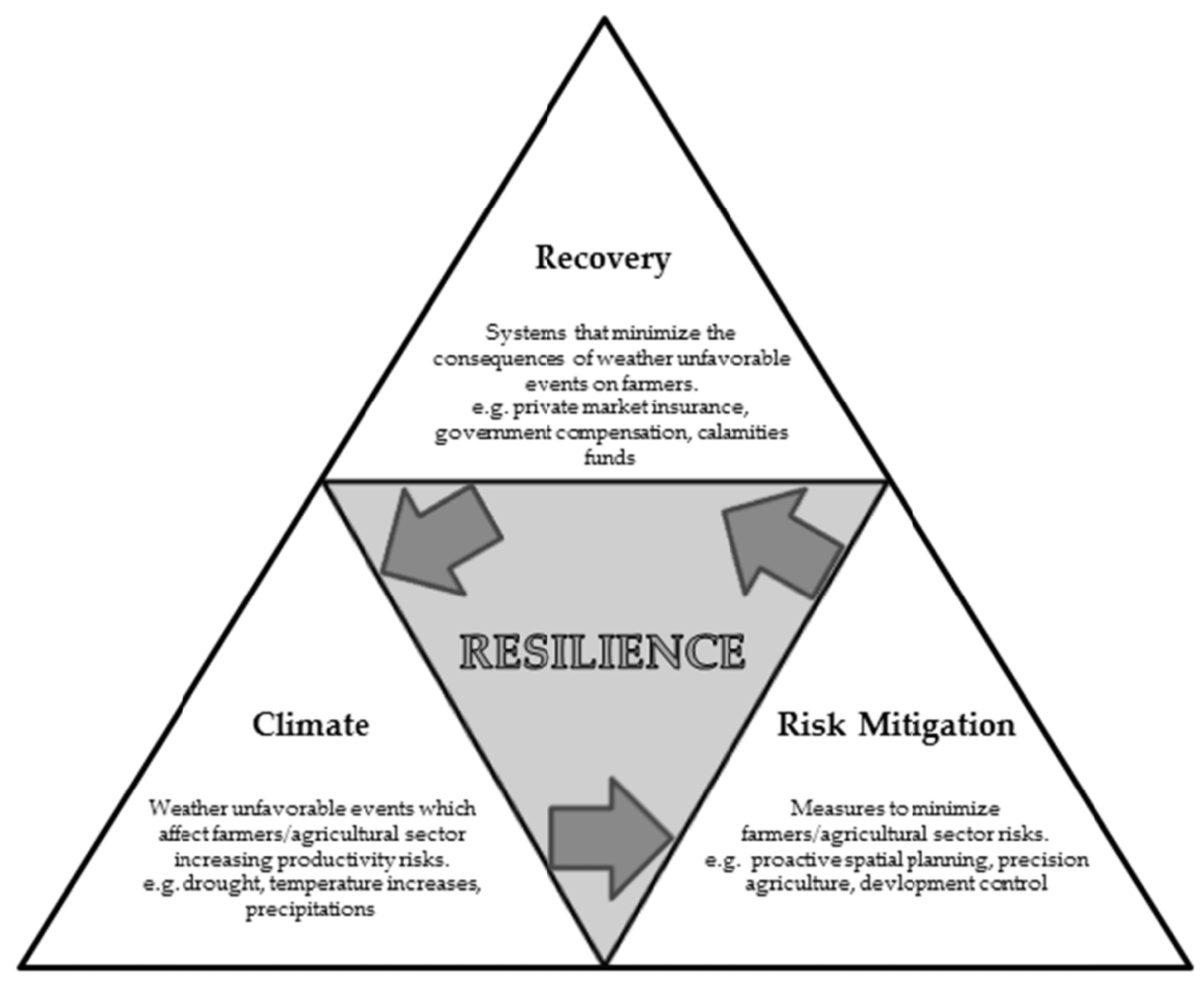

Figure 1. Climate-Risk-Recovery theoretical scheme

With these preliminary remarks, carrying out this analysis we wish to point out which factors could affect crop insurance policies in Italy, taking into account agroclimatic variables.

This paper is structured as follows: Section 2 is devoted to a literature review concerning crop insurance divided into theoretical and empirical literature. Section 3 presents the choices of the variables. Section 4 reports the results and discussion of the study, focusing on the implications of the results in the Italian agricultural insurance market. 


\section{Literature Review}

\subsection{Theoretical Approach}

In analyzing crop insurance, older literature identifies two problems that may cause adverse selection: the relationship between insurance rate making and expected yields for individual farmers, and the bias introduced in coverage protection where trends are not used to establish expected yields (Skees and Re, 1986).

Going in depth in these issues, Luo et al. (1994) investigates the potential usefulness of seasonal weather information in predicting corn yields for the Midwest, identifying a strong correlation between climatic weather information and adverse selection in agricultural insurance.

Kleindorfer and Klein (2003) introduce the problems associated with the effective economic design of markets for catastrophe insurance and the regulation of private companies offering such insurance.

In 2007, two studies show that there is a close correlation between poverty and natural disaster and impacts produced by climate change on smallholder and subsistence agriculture emphasizing the need to identify a theoretical model able to explain the impacts produced and the necessary resources (Barnett and Mahul, 2007; Morton, 2007).

Recently Aimin (2010) showed how climate change increases uncertainty and risk aversion in the people who work in the agricultural sector and the need to introduce risk management remedies.

Linnerooth-Bayer and Hochrainer-Stigler (2015) show how an overview of the disaster risk financing mechanisms could offset the reduction of disaster risk and the adaptation to climate change, especially in developing countries.

Ewert et al. (2015) seek to provide an overview on the current modeling of crops aiming at assessing the risks of climate change to food production and to what extent the crop models comply with the IAM (Integrated Assessment and Modelling) requirements.

Table 1. Theoretical literature

\begin{tabular}{|c|c|c|}
\hline Author(s) (Year) & Title & $\operatorname{Aim}(s)$ of the study \\
\hline Skees and $\operatorname{Re}(1986)$ & $\begin{array}{l}\text { Rate Making for Farm-Level Crop } \\
\text { Insurance: Implications for Adverse } \\
\text { Selection }\end{array}$ & $\begin{array}{l}\text { This research identifies two problems in the } \\
\text { new Federal Crop Insurance that may cause } \\
\text { adverse selection: the relationship between } \\
\text { rate making and expected yields for } \\
\text { individual farmers, and the bias introduced } \\
\text { in coverage protection when trends are not } \\
\text { used to establish expected yields. }\end{array}$ \\
\hline Luo et al. (1994) & $\begin{array}{l}\text { Weather Information and the Potential } \\
\text { for Intertemporal Adverse Selection in } \\
\text { Crop Insurance }\end{array}$ & $\begin{array}{l}\text { This study investigates the potential } \\
\text { usefulness of early-season weather } \\
\text { information in forecasting corn yields for the } \\
\text { Midwest }\end{array}$ \\
\hline $\begin{array}{l}\text { Kleindorfer and Klein } \\
\qquad(2003)\end{array}$ & $\begin{array}{l}\text { Regulation and Markets for } \\
\text { Catastrophe Insurance }\end{array}$ & $\begin{array}{l}\text { This paper discusses some of the problems } \\
\text { associated with the effective economic } \\
\text { design of markets for catastrophe insurance } \\
\text { and the regulation of private companies } \\
\text { offering such insurance. }\end{array}$ \\
\hline Barnett and Mahul (2007) & $\begin{array}{c}\text { Weather index insurance for agriculture } \\
\text { and rural areas in lower-income } \\
\text { countries }\end{array}$ & $\begin{array}{l}\text { This article discusses the link between } \\
\text { weather risk and poverty. }\end{array}$ \\
\hline
\end{tabular}


Morton (2007)

Aimin (2010)

Linnerooth-Bayer and

Hochrainer-Stigler (2015)

Ewert et al. (2015)
The impact of climate change on smallholder and subsistence agriculture

Uncertainty, Risk Aversion and Risk Management in Agriculture

Weather Based Crop Insurance in India

Financial instruments for disaster risk management and climate change adaptation

Crop modelling for integrated assessment of risk to food production from climate change
This paper proposes a conceptual framework for understanding the different forms of impact in an integrated way and identifying future research needs.

This paper tries to reveal whether a farmer's decision is risk averse or not through census data, and then the elements which affect farmer's decision under risk so as to produce the efficiency of crop planting.

This document provides a critical insight into the insurance market on India's meteorological index, a review of indexes used for insurance purposes and a description and analysis of common approaches to design and modeling.

This paper elaborates on this balance with an overview of disaster risk financing mechanisms and how they contribute to disaster risk reduction and climate change adaptation in developing countries.

This paper attempts to provide an overview of the present state of crop modelling to assess climate change risks to food production and to which extent crop models comply with IAM demands.

\subsection{Empirical Approach}

From an empirical perspective Hazell (1992), using insurance variables (premiums, administrative costs and indemnities) computes the efficiency of private-sector insurance under the absence of public constraints.

Smith and Goodwin (1996), using different insurance variables, i.e. crop insurance, chemical input, premium rate, yield, farmers' beliefs, farmers' preferences, debt to asset ratio, total from crop acres, proportion of total farm sales derived from livestock sales, percentage of cropped dryland wheat acres rented by the farm, off-farm labor income, show that dry wheat growers who subscribe to crop insurance use fewer agricultural chemicals.

Miranda and Glauber (1997), using an empirical model of the U.S. crop insurance market, find that U.S. crop insurer portfolios are twenty to fifty times riskier than they would be otherwise if yields were stochastically independent across farms. For this analysis they consider the total indemnities paid by conventional insurance and the total indemnities paid by crop insurers.

Just et al. (1998) demonstrate the relation between crop insurance and risk using the following insurance variables low price, medium price and high price. Wall and Smit (2005) use agroclimatic variables, such as climate risk and weather risk, to demonstrate the relevance of developing climate-adaptive policies.

Recently, literature has been given greater importance to agroclimatic variables. In particular, Rosenzweiga et al. (2014), considering CO2 concentration in the atmosphere, describe the response of crops to climate change, aiming at understanding the risks and opportunities in terms of food production and security. Shukla et al. (2015) demonstrate the role of temperature on the California drought in 2014 and examine the probability that this 
drought would have been less severe if temperatures resembled the historical climatology; and for the first time Lesk et al. (2016) try to estimate the national loss of cereal production due to extreme climatic disasters during the period 1964-2007 using drought, extreme heat, extreme cold and flood as variables of the analysis.

Partridge \& Wagner (2016) point out the need for adequate agricultural insurance schemes and identify the lack of such schemes in South Africa, particularly for small farmers. The empirical analysis considers both insurance variables such as single risk, yield, price, whole-farm, revenue, income, index based and agroclimatic variables as storms, floods, droughts, wildfires, earthquakes.

Table 2. Empirical literature

\begin{tabular}{|c|c|c|c|c|c|}
\hline Author(s) & Title & Area of study & $\begin{array}{c}\text { Agroclimatic } \\
\text { variables }\end{array}$ & $\begin{array}{c}\text { Insurance } \\
\text { variables }\end{array}$ & $\operatorname{Aim}(s)$ of the study \\
\hline $\begin{array}{l}\text { Hazell } \\
(1992)\end{array}$ & $\begin{array}{c}\text { The appropriate } \\
\text { role of } \\
\text { agricultural } \\
\text { insurance in } \\
\text { developing } \\
\text { countries }\end{array}$ & $\begin{array}{l}\text { Brazil, Costa } \\
\text { Rica, India, } \\
\text { Japan, Mexico, } \\
\text { Philippines, the } \\
\text { Usa }\end{array}$ & & $\begin{array}{l}\text { Premium, } \\
\text { administrativ } \\
\text { e costs, } \\
\text { indemnities }\end{array}$ & $\begin{array}{l}\text { The Author tries to } \\
\text { demonstrate the efficiency } \\
\text { of private-sector insurance } \\
\text { if the public breaks certain } \\
\text { constraints. }\end{array}$ \\
\hline $\begin{array}{c}\text { Smith and } \\
\text { Goodwin } \\
(1996)\end{array}$ & $\begin{array}{l}\text { Crop Insurance, } \\
\text { Moral Hazard, } \\
\text { and Agricultural } \\
\text { Chemical Use }\end{array}$ & Kansas & & $\begin{array}{c}\text { Crop } \\
\text { insurance, } \\
\text { chemical } \\
\text { input, } \\
\text { premium rate, } \\
\text { yield, NDR, } \\
\text { risk }\end{array}$ & $\begin{array}{l}\text { The results strongly } \\
\text { indicate that dryland wheat } \\
\text { producers who purchase } \\
\text { crop insurance use fewer } \\
\text { agricultural chemicals. }\end{array}$ \\
\hline $\begin{array}{l}\text { Miranda } \\
\text { and } \\
\text { Glauber } \\
\text { (1997) }\end{array}$ & $\begin{array}{l}\text { Systemic Risk, } \\
\text { Reinsurance, and } \\
\text { the Failure of } \\
\text { Crop Insurance } \\
\text { Markets }\end{array}$ & $\begin{array}{c}\text { the United States } \\
\text { of America }\end{array}$ & & $\begin{array}{c}\text { Total } \\
\text { indemnities } \\
\text { paid by } \\
\text { conventional } \\
\text { insurance, } \\
\text { total } \\
\text { indemnities } \\
\text { paid by crop } \\
\text { insurers }\end{array}$ & $\begin{array}{l}\text { An empirical model of the } \\
\text { U.S. crop insurance } \\
\text { market finds that U.S. crop } \\
\text { insurer portfolios are } \\
\text { twenty to fifty times } \\
\text { riskier than they would be } \\
\text { otherwise if yields were } \\
\text { stochastically independent } \\
\text { across farms. }\end{array}$ \\
\hline $\begin{array}{c}\text { Just et al. } \\
\text { (1998) }\end{array}$ & $\begin{array}{c}\text { Adverse } \\
\text { Selection in Crop } \\
\text { Insurance: } \\
\text { Actuarial and } \\
\text { Asymmetric } \\
\text { Information } \\
\text { Incentives }\end{array}$ & $\begin{array}{l}\text { the United States } \\
\text { of America }\end{array}$ & & $\begin{array}{l}\text { Low price, } \\
\text { medium } \\
\text { price, high } \\
\text { price }\end{array}$ & $\begin{array}{l}\text { The paper shows that the } \\
\text { major difference between } \\
\text { insured and non-insured } \\
\text { farmers is that insured } \\
\text { farmers tend to receive } \\
\text { sufficient expected } \\
\text { benefits to merit } \\
\text { participation even under } \\
\text { neutral risk. }\end{array}$ \\
\hline
\end{tabular}




\begin{tabular}{|c|c|c|c|c|c|}
\hline $\begin{array}{l}\text { Von } \\
\text { Ungern-St } \\
\text { ernberg } \\
\text { (2003) }\end{array}$ & $\begin{array}{l}\text { State intervention } \\
\text { on the market for } \\
\text { natural damage } \\
\text { insurance in } \\
\text { Europe }\end{array}$ & $\begin{array}{l}\text { Britain, Spain, } \\
\text { France, } \\
\text { Switzerland, } \\
\text { Germany }\end{array}$ & & $\begin{array}{l}\text { Premiums, } \\
\text { claims, } \\
\text { surplus, } \\
\text { increase in } \\
\text { reserve }\end{array}$ & $\begin{array}{l}\text { The paper summarizes the } \\
\text { results of studies of the } \\
\text { property insurance market } \\
\text { in } 5 \text { countries, Britain, } \\
\text { Spain, France, Switzerland } \\
\text { and Germany. }\end{array}$ \\
\hline & Climate Change & & & & $\begin{array}{l}\text { Integration is a key feature } \\
\text { for both practicing and } \\
\text { promoting sustainable } \\
\text { agriculture and for } \\
\text { developing climate change }\end{array}$ \\
\hline $\begin{array}{l}\text { Wall and } \\
\text { Smit } \\
(2005)\end{array}$ & $\begin{array}{l}\text { Adaptation in } \\
\text { Light of } \\
\text { Sustainable } \\
\text { Agriculture }\end{array}$ & Canada & $\begin{array}{l}\text { Climate risk, } \\
\text { weather risk. }\end{array}$ & & $\begin{array}{l}\text { adaptation } \\
\text { Producers rarely make } \\
\text { decisions for their } \\
\text { operations } \\
\text { weighing a number of } \\
\text { issues, possible outcomes, } \\
\text { and desired results. }\end{array}$ \\
\hline $\begin{array}{l}\text { Picard } \\
(2008)\end{array}$ & $\begin{array}{l}\text { Natural disaster } \\
\text { insurance and the } \\
\text { equity-efficiency } \\
\text { trade-off }\end{array}$ & & & $\begin{array}{l}\text { Low risk } \\
\text { areas, high } \\
\text { risk areas, } \\
\text { government } \\
\text { budget } \\
\text { constraints }\end{array}$ & $\begin{array}{l}\text { The article investigates the } \\
\text { equity-efficiency trade-off } \\
\text { in the regulation of natural } \\
\text { disaster insurance. }\end{array}$ \\
\hline $\begin{array}{l}\text { Rosenzwei } \\
\text { g, et al. } \\
\text { (2014) }\end{array}$ & $\begin{array}{l}\text { Assessing } \\
\text { agricultural risks } \\
\text { of climate change } \\
\text { in the } 21 \mathrm{st} \\
\text { century in a } \\
\text { global gridded } \\
\text { crop model } \\
\text { intercomparison }\end{array}$ & World & $\begin{array}{c}\mathrm{CO}_{2} \text {, effect of } \\
\mathrm{CO}_{2} \text {, impact of } \\
\mathrm{CO}_{2}\end{array}$ & & $\begin{array}{l}\text { The models used in the } \\
\text { GGCM intercomparison } \\
\text { analyze the response of } \\
\text { crops to climate change to } \\
\text { better understand risks and } \\
\text { opportunities in regard to } \\
\text { food production and food } \\
\text { security. }\end{array}$ \\
\hline $\begin{array}{l}\text { Shukla et } \\
\text { al. (2015) }\end{array}$ & $\begin{array}{c}\text { Temperature } \\
\text { impacts on the } \\
\text { water year } 2014 \\
\text { drought in } \\
\text { California }\end{array}$ & California & $\begin{array}{l}\text { Precipitation, } \\
\text { temperature }\end{array}$ & & $\begin{array}{l}\text { This study shows that } \\
\text { although low precipitation } \\
\text { was the main driver of the } \\
\text { WY } 2014 \text { drought } \\
\text { conditions in California, } \\
\text { temperature played an } \\
\text { important role in } \\
\text { exacerbating the drought. }\end{array}$ \\
\hline
\end{tabular}




\begin{tabular}{|c|c|c|c|c|c|}
\hline $\begin{array}{l}\text { Lesk et al. } \\
\text { (2016) }\end{array}$ & $\begin{array}{l}\text { Influence of } \\
\text { extreme weather } \\
\text { on disaster on } \\
\text { global crop } \\
\text { production }\end{array}$ & World & $\begin{array}{c}\text { Drought, } \\
\text { extreme heat, } \\
\text { extreme cold, } \\
\text { flood }\end{array}$ & & $\begin{array}{l}\text { The Authors try to } \\
\text { estimate for the first time, } \\
\text { national cereal production } \\
\text { losses across the globe } \\
\text { resulting from reported } \\
\text { extreme weather disasters } \\
\text { during 1964-2007. }\end{array}$ \\
\hline $\begin{array}{l}\text { Partridge } \\
\text { and } \\
\text { Wagner } \\
(2016)\end{array}$ & $\begin{array}{l}\text { Risky Business: } \\
\text { Agricultural } \\
\text { Insurance in the } \\
\text { Face of Climate } \\
\text { Change }\end{array}$ & South Africa & $\begin{array}{l}\text { Storms, floods, } \\
\text { droughts, } \\
\text { wildfires, } \\
\text { earthquakes }\end{array}$ & $\begin{array}{c}\text { Single risk, } \\
\text { yield, price, } \\
\text { whole-farm, } \\
\text { revenue, } \\
\text { income, index } \\
\text { based }\end{array}$ & $\begin{array}{l}\text { This paper aims to } \\
\text { highlight the need for } \\
\text { appropriate agricultural } \\
\text { insurance schemes and } \\
\text { identifies the lack of such } \\
\text { schemes in South Africa, } \\
\text { especially for smallholder } \\
\text { farmers. }\end{array}$ \\
\hline
\end{tabular}

\section{Materials and Methods}

Data on precipitation, average, maximum and minimum temperatures for the 2004-2011 period for each Italian province, considered in this study, have been extracted from the National Agrometeorological Database of the Minister of food, agricultural and forestry policies database (MIPAAF). The latter contains agro-meteo-climatic data, estimated using daily weather data of the RAN stations, the Military Air Force Service and the Italian regional services. In particular, the Precipitation variable refers to the quantity of rainfall measured in millimeters $(\mathrm{mm})$. Average Temperature indicates the average annual temperature retrieved in each province on a daily basis. Data on Maximum Temperature and Minimum Temperature, expressed in Celsius degrees $\left({ }^{\circ} \mathrm{C}\right)$, indicates respectively the average value of highest and lowest annual temperatures retrieved by the agro-meteorological stations in each Italian province.

Data on phytosanitary product utilization, total cultivated surface, agricultural production and the labor force in the agricultural sector for the same time window in the same Italian provinces have been acquired from the Italian National Statistics Institute (ISTAT). The latter is a public research institution, leading official statistic producer to support citizens and public decision-makers. Total cultivated surface measures the total hectares (ha) of an area destined to cultivation of all types of crops. The agricultural production variable represents instead the total amount of produced crops expressed in quintals (q). Phytosanitary product utilization refers to the quantities expressed in kilograms $(\mathrm{kg})$ of active substances or active ingredients distributed during the cultivation process and coded by ISTAT with the collaboration of the Agrofarma Company. The labor force in agriculture is measured by the number of people (expressed in thousands) employed in the agricultural sector.

Figures regarding the Certificates, Insured Values and Total Premiums for the same time window aggregated for each Italian province have been acquired from the Database on Agricultural Hazards (SICURAGRO). The Risk Database in Agriculture was established by ISMEA with a Decree of the Ministry of Food and Forestry Policies of 18 July 2003 and aims at supporting public intervention for agricultural risk management and providing informative elements for shareholders, also for the purpose of risk prevention. The Certificates variable indicates the number of agricultural products insured against atmospheric adversities. The Insured Value represents the value of insured agricultural products expressed in thousands of euro $(1,000 €)$, against adverse weather conditions. The Total Premium indicates the amount in thousands of euro $(1,000 €)$ paid by the insured farmer on the basis of the insurance contract. 
Table 3. Sources of data

\begin{tabular}{|c|c|c|c|}
\hline Source of data & Data acquired & Time period & Area of study \\
\hline \multirow{4}{*}{ MIPAAF } & Precipitation (mm) & \multirow{11}{*}{ From 2004 to 2011} & \multirow{11}{*}{ Italian provinces } \\
\hline & Medium temperature $\left({ }^{\circ} \mathrm{C}\right)$ & & \\
\hline & Maximum temperature $\left({ }^{\circ} \mathrm{C}\right)$ & & \\
\hline & Minimum temperature $\left({ }^{\circ} \mathrm{C}\right)$ & & \\
\hline \multirow{4}{*}{ ISTAT } & Phytosanitary product (kg) & & \\
\hline & Total cultivated surface (ha) & & \\
\hline & Agricultural production (q) & & \\
\hline & Labor force $(1,000$ workers $)$ & & \\
\hline \multirow{3}{*}{ SICURAGRO } & Certificates (no.) & & \\
\hline & Insured Value $(1,000 €)$ & & \\
\hline & Total Premium $(1,000 €)$ & & \\
\hline
\end{tabular}

The models are estimated for the 101 Italian provinces in which reliable data exist for the phytosanitary product, precipitation, medium temperature, maximum temperature, minimum temperature, total cultivate surface, agricultural production, labor force, certification, insured value, total premium and reimbursed premium.

We analyzed the panel data for the period from 2004 to 2011 given that it was the only time span for which all the variables were present.

Using pooled OLS regression, as a statistical method used in econometrics to analyze two-dimensional panel data, three analyses have been conducted to verify the robustness of empirical results. Three dependent variables, i.e Total Premiums, Insured Values and Certificates, for each model have been regressed on independent variables in logarithmic specification, i.e. phytosanitary product (LnPhyto), precipitation (LnPrec), medium temperature (LnTaverage), maximum temperature $(\operatorname{LnTmax})$, minimum temperature $(\operatorname{LnTmin})$, total cultivate surface (LnTotSurf), agricultural production (LnAgrProd), labor force (LnAgrLab).

\section{Ln Total Premiums, t}

$$
\begin{aligned}
& =\alpha_{1}+\beta_{1} \text { Ln Prec }_{i, t-1}+\beta_{2} \text { Ln TotSurf }_{i, t-1}+\beta_{3}{\text { Ln } \text { AgrProd }_{i, t-1}+\beta_{4} \text { Ln Phyto }_{i, t-1}} \\
& +\beta_{5} \text { Ln AgrLab }_{t-1}+\beta_{6}{\text { Ln } \text { Taverage }_{i, t-1}}+\beta_{7} \text { Tmax }_{i, t-1}+\beta_{7} \operatorname{Tmin}_{i, t-1}+\varepsilon_{1, t}
\end{aligned}
$$

Ln Insured Value ${ }_{i, t}$

$$
\begin{aligned}
& =\alpha_{1}+\beta_{1} \operatorname{LnPrec}_{i, t-1}+\beta_{2} \text { Ln TotSurf }_{i, t-1}+\beta_{3} \operatorname{Ln}_{\text {AgrProd }_{i, t-1}}+\beta_{4} \text { Ln Phyto }_{i, t-1} \\
& +\beta_{5} \text { Ln AgrLab, }_{t-1}+\beta_{6} \text { Ln Taverage }_{i, t-1}+\beta_{7} \text { Tmax }_{i, t-1}+\beta_{7} \operatorname{Tmin}_{i, t-1}+\varepsilon_{1, t}
\end{aligned}
$$

Ln Certificates $_{i, t}$

$$
\begin{aligned}
& =\alpha_{1}+\beta_{1} \text { Ln Prec }_{i, t-1}+\beta_{2} \text { Ln TotSurf }_{i, t-1}+\beta_{3} \operatorname{Ln}_{\text {AgrProd }_{i, t-1}}+\beta_{4} \text { Ln Phyto }_{i, t-1} \\
& +\beta_{5} \text { Ln AgrLab, }_{t-1}+\beta_{6} \text { Ln Taverage }_{i, t-1}+\beta_{7} \operatorname{Tmax}_{i, t-1}+\beta_{7} \operatorname{Tmin}_{i, t-1}+\varepsilon_{1, t}
\end{aligned}
$$


Table 4. Summary statistics

\begin{tabular}{lcccc}
\hline Variables & Mean & Standard deviation & Minimum & Maximum \\
\hline Precipitation $(\mathrm{mm})$ & 792.19 & 177.32 & 406.00 & $1,378.70$ \\
Medium temperature $\left({ }^{\circ} \mathrm{C}\right)$ & 13.40 & 2.86 & 2.25 & 19.15 \\
Minimum temperature $\left({ }^{\circ} \mathrm{C}\right)$ & 8.74 & 2.96 & 0.00 & 15.60 \\
Maximum temperature $\left({ }^{\circ} \mathrm{C}\right)$ & 18.10 & 2.97 & 5.50 & 23.40 \\
Total cultivated surface $(\mathrm{ha})$ & $125,601.78$ & $101,047.64$ & $5,374.10$ & $607,673.04$ \\
Agricultural production $(\mathrm{q})$ & $6,046,470.07$ & $5,674,696.07$ & $12,034.00$ & $44,035,509.00$ \\
Labor force $(1,000$ workers) & 9.60 & 9.50 & 0.14 & 77.14 \\
Phytosanitary product $(\mathrm{kg})$ & $1,477,014.47$ & $1,605,266.69$ & $5,765.00$ & $9,941,943.00$ \\
Certificates $($ no. $)$ & $2,235.37$ & $3,222.94$ & 0.70 & $15,980.00$ \\
Insured Value $(1,000 €)$ & $46,869,185.90$ & $67,890,870.61$ & $5,733.00$ & $403,652,352.50$ \\
Total Premium $(1,000 €)$ & $2,935,997.36$ & $5,491,519.71$ & 114.76 & $35,769,970.36$ \\
\hline
\end{tabular}

After the empirical analysis, spatial distributions of average relevant variables over the period 2004-2011 among Italian provinces have been drawn in order to highlight graphically the relations investigated in the models.

\section{Results and Discussion}

The following Table 5 shows how the variables just defined have an impact on: Total Premium, Insured Value and Certificates.

It is important to underline how the dependent and independent variables do not act on the same temporal level; the independent variables are delayed referring to (t-1) period with respect to the time (t) to which the dependent variables refer.

Table 5. Regression results for each model considered in the study

\begin{tabular}{|c|c|c|c|}
\hline & $\begin{array}{c}\text { Ln Total Premiums } \\
\text { (1) }\end{array}$ & $\begin{array}{c}\text { Ln Insured Value } \\
\text { (2) }\end{array}$ & $\begin{array}{c}\text { Ln Certificates } \\
\text { (3) }\end{array}$ \\
\hline $\operatorname{Ln}_{\operatorname{Prec}_{t-1}}$ & $\begin{array}{c}-1.028^{* *} \\
0.4640\end{array}$ & $\begin{array}{c}-1.1075 * * * \\
0.3879\end{array}$ & $\begin{array}{c}-1.0797 * * * \\
0.3821\end{array}$ \\
\hline Ln TotSurf $t-1$ & $\begin{array}{c}-0.0584 \\
0.2394\end{array}$ & $\begin{array}{c}-0.3940 * * \\
0.1888\end{array}$ & $\begin{array}{c}-0.2402 \\
0.2155\end{array}$ \\
\hline Ln AgrProd $_{t-1}$ & $\begin{array}{c}0.3234 * * \\
0.1250\end{array}$ & $\begin{array}{c}0.2125^{* *} \\
0.0894\end{array}$ & $\begin{array}{c}0.3485^{* *} \\
0.1549\end{array}$ \\
\hline Ln Phyto $_{t-1}$ & $\begin{array}{c}0.8580^{* *} \\
0.1438\end{array}$ & $\begin{array}{c}0.7137 * * * \\
0.1309\end{array}$ & $\begin{array}{c}0.7663 * * * \\
0.1471\end{array}$ \\
\hline Ln $A g r L a b_{t-1}$ & $\begin{array}{l}0.2398 \\
0.2495\end{array}$ & $\begin{array}{c}0.4444 * * \\
0.2037\end{array}$ & $\begin{array}{l}0.0407 \\
0.2606\end{array}$ \\
\hline Ln Taverage $_{t-1}$ & $\begin{array}{c}-3.9370^{*} \\
2.0014\end{array}$ & $\begin{array}{c}-0.1534 \\
0.2165\end{array}$ & $\begin{array}{c}-4.4067 * * \\
1.9667\end{array}$ \\
\hline $\operatorname{Ln}_{\operatorname{Tmin}_{t-1}}$ & $\begin{array}{c}0.4435^{* *} \\
0.2170\end{array}$ & $\begin{array}{l}-0.1383 \\
0.1929\end{array}$ & $\begin{array}{c}0.5057 * * \\
0.1997\end{array}$ \\
\hline $\operatorname{Ln} \operatorname{Tmax}_{t-1}$ & $\begin{array}{c}-0.1629 * * \\
2.4186\end{array}$ & $\begin{array}{l}0.3321 \\
1.5311\end{array}$ & $\begin{array}{l}0.6201 \\
2.3020\end{array}$ \\
\hline \multicolumn{4}{|c|}{ Summary Statistics } \\
\hline SER & 1.5943 & 1.3739 & 1.5303 \\
\hline Adjusted $R^{2}$ & 0.5132 & 0.4996 & 0.4360 \\
\hline
\end{tabular}


The columns labeled (1), (2), and (3) included in Table 5, report the results of the three-separate pooled OLS regressions. The values in the table are the coefficients, standard errors (in parentheses), their p-values, and summary statistics, as indicated by the description in each row.

The first column labeled (1) considers a linear relation between the dependent variable Ln Total Premium and the independent variables. The second column labeled (2) considers a linear relation between the dependent variable Ln Insured Value and the independent variables. Regression (3) instead uses as a dependent variable the Ln Certificates helping us to establish whether the tested analyses provide robust results.

The results of the first regression analysis show how significant the precipitation variable is. The decreasing value of rainfall has the effect of increasing the value of the total premium; in particular a variation of $1 \%$ in the precipitation variable originates a consequent negative variation of $1 \%$ in the Total Premiums of the subsequent year.

The same effect can be observed focusing on the minimum temperature. In the presence of drought (lower precipitation and higher minimum temperatures) our dependent variable (1) tends to increase.

Furthermore, the analysis shows a close relation between Agricultural Production and Total premiums; in particular, a variation of $1 \%$ in the Agricultural Production variable originates a consequent positive variation around of $0.3 \%$ in the Total Premiums of the subsequent year ( $\mathrm{p}$-value $<0.05$ ). The same effect can be observed focusing on the Phytosanitary Product; to an increase of $1 \%$ produce a variation around of $0.8 \%$ in the Total Premiums of the subsequent year ( $\mathrm{p}$-value $<0.05$ ), confirming the linear relation between agriculture production and phytosanitary products.

Focusing on the summary statistics of regression (1), it is possible to notice that the adjusted $\mathrm{R}^{2}$ assumes a value equal to 0.5132 , quantifying the extent to which the explanatory variables explain the variation in the dependent variable.

The estimates in regression (2), in line with those in column (1) highlight the same relation with the insurance premium: with a reduction of precipitation of $1 \%$ (in the presence of drought), the dependent variable Insured value tends to increase of $1 \%$ ( $\mathrm{p}$-value $<0.001)$.

Furthermore, the analysis shows a close relation between Agricultural Production and Insured Value. In fact, in particular an increase of $1 \%$ in the Agricultural Production variable originates a consequent positive variation around of $0.2 \%$ in the Insured Value of the subsequent year. In this case $\mathrm{R}^{2}$ assumes a value equal to 0.4996 .

The third variable considered is the number of certificates. The analysis shows results consistent with the other two dependent variables previously analyzed; in presence of drought the number of certificates tends to increase.

The reduction in rainfall increases the value of the Certificates: an increase of $1 \%$ in the precipitation variable originates a consequent negative variation of $1 \%$ in the Certificates of the subsequent year ( $\mathrm{p}$-value $<0.001$ ). The same effect emerges in the linear relationship between the independent variable minimum temperature and the variable Certificates.

Focusing on the summary statistics of regression (3), it is possible to notice that the adjusted $\mathrm{R}^{2}$ shows a value equal to 0.4360 , quantifying the extent to which the explanatory variables explain the variation in the dependent variable.

As illustrated in Figure 2, the levels of average annual precipitation and minimum temperatures in the Italian provinces go hand in hand with the spreading of insurance certificates, and confirm the results of empirical analysis. 

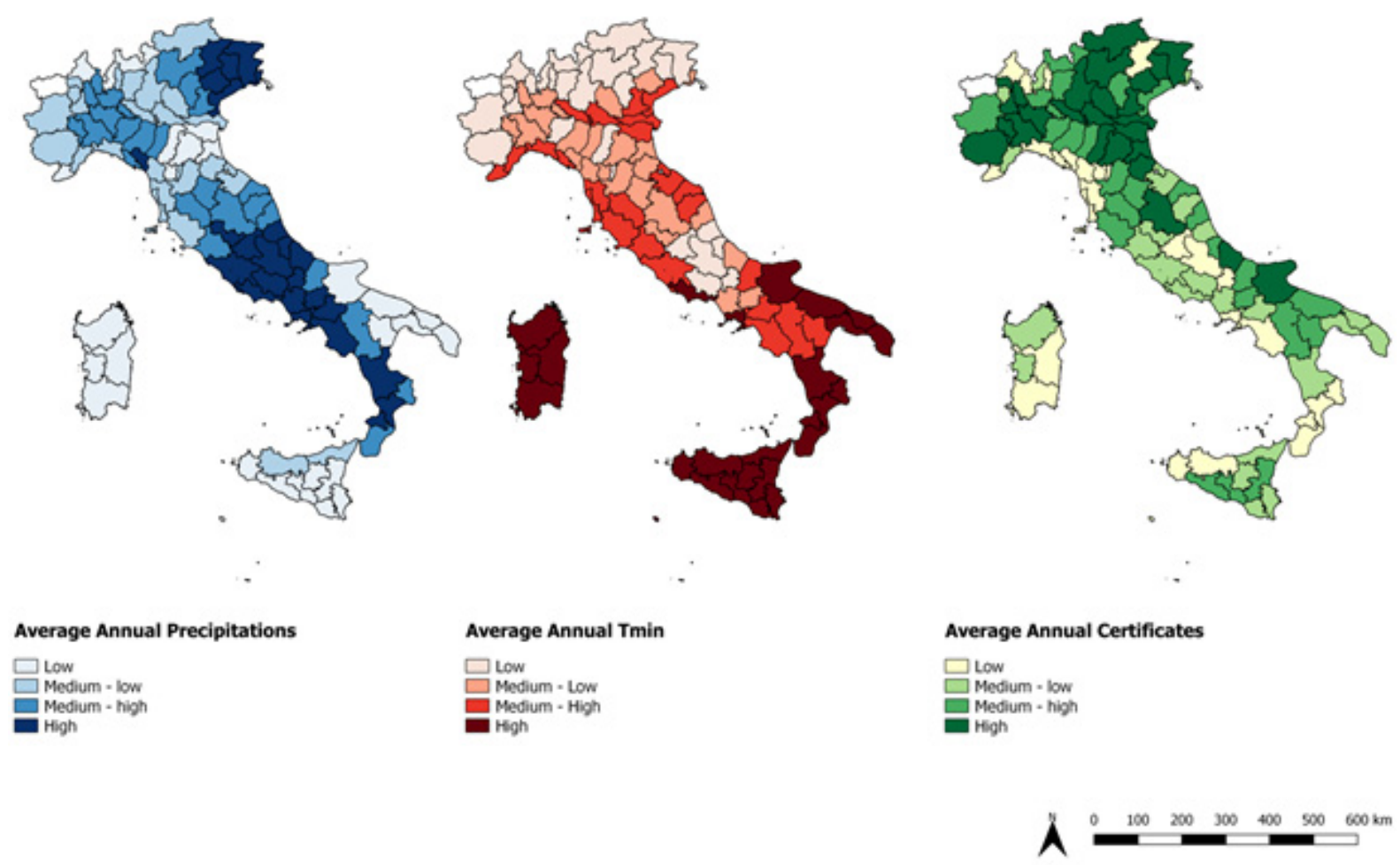

Figure 2. Spatial distribution of average annual precipitation, minimum temperature and insurance certificates

\section{Conclusions}

As a primary objective, this paper focuses on the relation between insurance variables and agroclimatic variables, such as the different levels of precipitation and temperature, focusing in particular on the drought phenomenon.

Specifically, it has been proven that with a decrease in precipitation and an increase in temperature the need to cover risks with adequate insurance instruments increases.

The analysis confirms that climate factors represent an incentive for the adoption of insurance instruments highlighting the necessity to increase farmers' information and to support insurance instruments through public subsidies.

In the light of these results, we can conclude that adverse climatic events should not be considered as exceptional events, but as one of the negative externalities with which the agricultural enterprise must live. This major concern, especially in the agricultural sector particularly vulnerable to adverse climatic events, shows the importance of providing suitable financial hedging instruments for farmers.

\section{References}

Aimin, H. (2010). Uncertainty, risk aversion and risk management in agriculture. Agriculture and agricultural science procedia, 1, 152-156. http://dx.doi.org/10.1016/j.aaspro.2010.09.018

Barnett, B. J., \& Mahul, O. (2007). Weather index insurance for agriculture and rural areas in lower-income countries. American Journal of Agricultural Economics, 89(5), 1241-1247. http://dx.doi.org/10.1111/j.1467-8276.2007.01091.x

Clarke, D. J., Clarke, D., Mahul, O., Rao, K. N., \& Verma, N. (2012). Weather based crop insurance in India. Policy Research working paper; no. WPS 5985. Washington, DC: World Bank.

Costanza, R. (1991). Assuring sustainability of ecological economic systems. In R. Costanza (Ed.), Ecological Economics: The Science and Management of Sustainability (pp. 331-343). New York, USA: Columbia University Press. 
Darnhofer, I. (2014). Resilience and why it matters for farm management. European Review of Agricultural Economics, 41(3), 461-484. http://dx.doi.org/10.1093/erae/jbu012

Ewert, F., Rötter, R. P., Bindi, M., Webber, H., Trnka, M., Kersebaum, K. C. ... Semenov, M. A. (2015). Crop modelling for integrated assessment of risk to food production from climate change. Environmental Modelling \& Software, 72, 287-303. http://dx.doi.org/10.1016/j.envsoft.2014.12.003

Gómez Gómez, C. M., \& Pérez Blanco, C. D. (2012). Do drought management plans reduce drought risk? A risk assessment model for a Mediterranean river basin. Ecological Economics, 76, 42-48. http://dx.doi.org/10.1016/j.ecolecon.2012.01.008

Hazell, P. B. (1992). The appropriate role of agricultural insurance in developing countries. Journal of International Development, 4(6), 567-581. http://dx.doi.org/10.1002/jid.3380040602

Hazell, P. B., \& Hess, U. (2010). Drought insurance for agricultural development and food security in dryland areas. Food Security, 2(4), 395-405. http://dx.doi.org/10.1007/s12571-010-0087-y

ISMEA. (2017). http://www.ismea.it/flex/FixedPages/IT/Sicuragro.php/L/IT

ISTAT. (2017). http://dati.istat.it/Index.aspx?DataSetCode=DCSP_COLTIVSPA

ISTAT. (2017). http://dati.istat.it/Index.aspx?DataSetCode=DCSP_COLTIVAZ

ISTAT. (2017). http://dati.istat.it/Index.aspx?DataSetCode=DCSP_FITOSANITARI\#

Just, R. E., Calvin, L., \& Quiggin, J. (1999). Adverse selection in crop insurance: Actuarial and asymmetric information incentives. American Journal of Agricultural Economics, 81(4), 834-849. http://dx.doi.org/10.2307/1244328

Kleindorfer, P. R., \& Klein, R. W. (2003). Regulation and markets for catastrophe insurance. In M. Sertel \& S. Koray (Eds.), Advances in Economic Design (pp. 263-279). Berlin, Germany: Springer-Verlag Berlin Heidelberg.

Landini, S. (2015). Agricultural risk and its insurance in Italy. European Insurance Law Review, 31-38.

Lesk, C., Rowhani, P., \& Ramankutty, N. (2016). Influence of extreme weather disasters on global crop production. Nature, 529, 84-87. http://dx.doi.org/10.1038/nature16467

Linnerooth-Bayer, J., \& Hochrainer-Stigler, S. (2015). Financial instruments for disaster risk management and climate change adaptation. Climatic Change, 133(1), 85-100. http://dx.doi.org/10.1007/s10584-013-1035-6

Luo, H., Skees, J. R., \& Marchant, M. A. (1994). Weather information and the potential for intertemporal adverse selection in crop insurance. Review of Agricultural Economics, 16(3), 441-451.

Mahul, I., \& Vermersch, D. (2000). Hedging crop risk with yield insurance futures and options. European review of agricultural economics, 27(2), 109-126. http://dx.doi.org/10.1093/erae/27.2.109

MIPAAF https://www.politicheagricole.it/flex/FixedPages/Common/miepfy700_riferimentiAgro.php/L/IT?name=P

Miranda, M. J., \& Glauber, J. W. (1997). Systemic risk, reinsurance, and the failure of crop insurance markets. American Journal of Agricultural Economics, 79(1), 206-215. http://dx.doi.org/10.2307/1243954

Morton, J. F. (2007). The impact of climate change on smallholder and subsistence agriculture. Proceedings of the National Academy of Sciences, 104(50), 19680-19685. http://dx.doi.org/10.1073/pnas.0701855104

Partridge, A. G., \& Wagner, N. J. (2016). Risky business: agricultural insurance in the face of climate change. Agriprobe, 13(3), 49-53.

Picard, P. (2008). Natural Disaster Insurance and the Equity-Efficiency Trade-Off. Journal of Risk and Insurance, 75(1), 17-38. http://dx.doi.org/10.1111/j.1539-6975.2007.00246.x

Porrini, D., \& Schwarze, R. (2014). Insurance models and European climate change policies: an assessment. European Journal of Law and Economics, 38, 7-28. http://dx.doi.org/10.1007/s10657-012-9376-6

Rosenzweig, C., Elliott, J., Deryng, D., Ruane, A. C., Müller, C., Arneth, A. ... Neumann, K. (2014). Assessing agricultural risks of climate change in the 21st century in a global gridded crop model intercomparison. Proceedings of the National Academy of Sciences, 111(9), 3268-3273. http://dx.doi.org/10.1073/pnas.1222463110

Shukla, S., Safeeq, M., AghaKouchak, A., Guan, K., \& Funk, C. (2015). Temperature impacts on the water year 2014 drought in California. Geophysical Research Letters, 42(11), 4384-4393. 
http://dx.doi.org/10.1002/2015GL063666

Skees, J. R., \& Reed, M. R. (1986). Rate making for farm-level crop insurance: Implications for adverse selection. American Journal of Agricultural Economics, 68(3), 653-659.

Smith, V. H., \& Goodwin, B. K. (1996). Crop insurance, moral hazard, and agricultural chemical use. American Journal of Agricultural Economics, 78(2), 428-438.

Surminski, S. (2013). The Role of Insurance in Reducing Direct Risk - The Case of Flood Insurance. International Review of Environmental Resources Economics, 7, 241-278. http://dx.doi.org/10.1561/101.00000062

Toma, P., Miglietta, P. P., Zurlini, G., Valente, D., \& Petrosillo, I. (2017). A non-parametric bootstrap-data envelopment analysis approach for environmental policy planning and management of agricultural efficiency in EU countries. Ecological Indicators, 83, 132-143. http://dx.doi.org/10.1016/j.ecolind.2017.07.049

von Ungern-Sternberg, T. (2003). State intervention on the market for natural damage insurance in Europe. CESifo Working Paper, 1067.

Wall, E., \& Smit, B. (2005). Climate change adaptation in light of sustainable agriculture. Journal of sustainable agriculture, 27(1), 113-123. http://dx.doi.org/10.1300/J064v27n01_07

\section{Copyrights}

Copyright for this article is retained by the author(s), with first publication rights granted to the journal.

This is an open-access article distributed under the terms and conditions of the Creative Commons Attribution license (http://creativecommons.org/licenses/by/4.0/). 